\title{
PRE-SERVICE TEACHERS' PERCEPTION OF LEARNER AUTONOMY
}

\author{
Muhammad Iqbal Ripo Putra; Citra Iswara \\ Program of English Education, Faculty of Language and Arts Education, IKIP PGRI Pontianak \\ Jalan Ampera No. 88 Pontianak, Kalimantan Barat \\ ripoputra87@gmail.com, iswarac@upi.edu.com
}

\begin{abstract}
Pre-service teachers' limited understanding towards learner autonomy affects how they develop their own and their students' autonomy. Therefore, this study aimed to reveal: 1) the pre-service teachers' perception on the role of the teachers and students in learner autonomy; 2) the pre-service teachers' activity on their own learner autonomy as a learner in teacher training school. 25 respondents were surveyed to acquire their perception. It was found that the pre-service teachers assumed that the teachers should hold the dominant role and be responsible to the learning results. Not only to that, the pre-service teachers still focused on exam-oriented activity; learning only from material given by the teacher in order to pass the exam. Due to that perception, their autonomous learning did not properly develop, as they prefer teacher-centered method. To deal with these findings, the pre-service teachers should not orientate on passing the exam, but rather on the progress as learning is a process not only the result.
\end{abstract}

Key words: learner autonomy, pre-service teachers, perception

\begin{abstract}
ABSTRAK
Keterbatasan pemahaman para calon guru terhadap kemandirian belajar siswa berpengaruh pada bagaimana mereka menumbuhkan kemandirian bagi diri mereka sendiri dan kemandirian siswa. Oleh karena itu, penelitian ini bertujuan untuk menemukan: 1) persepsi para calon guru terhadap peran guru dan siswa dalam kemandirian belajar; 2) kegiatan para calon guru terhadap kemandirian belajar mereka sebagai siswa di sekolah profesi guru. 25 responden dilibatkan dalam penelitian ini. Penelitian ini menemukan bahwa para calon guru berpendapat bahwa para guru harus memegang peranan yg lebih banyak dan bertanggungjawab terhadap hasil pembelajaran. Tidak hanya itu, para calon guru hanya mementingkan kegiatan di kelas yang berorientasi pada ujian; pembelajaran yang hanya berdasarkan pada materi yang diberikan oleh guru di kelas untuk dapat lulus ujian. Didasari oleh persepsi ini, kemandirian belajar mereka tidak dapat berkembang dengan baik karena mereka lebih memilih menggunakan metode teacher centred. Berdasarkan hasil penelitian, para calon guru seharusnya tidak hanya berorientasi pada kelulusan ujian, tetapi lebih fokus kepada proses belajar bukan hasil.
\end{abstract}

Kata kunci: otonomi belajar, calon guru, persepsi 


\section{INTRODUCTION}

Learner autonomy gains its recognition in EFL teaching-learning in Asia lately. Learner autonomy gave the learner the chance to be independent in deciding what to learn and how to learn. Learner autonomy considered holding a significant effect on learners' achievement, including L2 proficiency. Despite the positive significant brought by learner autonomy, the development of learner autonomy in Indonesia is still have not be done properly due to teachers' varied perception to learner autonomy (i.e. inborn ability, learning alone, learned skill) (Agustina, 2017). Because of that, the teachers were not certain whether they could develop their students' learner autonomy. It means that teachers have to share the unanimous view on the natural science of learner autonomy in order to develop it properly. Not only to the teacher, the pre-service teachers as the future teachers, need to develop their understanding toward learner autonomy.

The pre-service teacher will eventually become the in-service teacher and gradually replacing the current teacher. In process of changing, the preservice teachers have to be aware of the current learning issue, including the development of learner autonomy. It is important for the pre-service teacher to understand and develop learner autonomy first before fostering it to their students (Little, 1991). For that reason, the pre-service teachers need to develop an understanding of the learner autonomy. However, a mere understanding of the meaning of learner autonomy is not enough. The pre-service teachers also need to understand their role as the teacher and the students' role as the subject of learner autonomy development. Because of that, this study intended to find out the pre-service teachers' perception of the teachers and students' role in the application of learner autonomy.

Regardless the learners' awareness of their learning progress, it does not mean that the learner did the learning all by themselves without teacher assisting. Esch (1996) stated that the role of the teacher is still needed in the classroom. Despite the learners' ability in managing their own learning, teacher's presence is still necessary as a controller, prompter, participant, resource, and tutor (Harmer, 2007). Additionally, Camilleri (1999) explains the role of the teacher as facilitator, coparticipants, advisor, encourager, monitor, the resource also as a patient person. In other words, the teachers' role in learning activity is still important. Although the students did most of the learning, teachers still required to assist, to facilitate and to encourage the students in the learning activity.

It is important for the teacher to understand the value and the principle of learner autonomy in order to implement it (Smith, 2003). In addition to that, Smith mentioned that teachers also need to develop their own teacher's autonomy. Where the teachers are independent in making a decision on what to teach and how to teach the learners. Hence that it is necessary for both teacher and learner to work together in order to develop the learner autonomy. On the contrary, teachers in Indonesia have not fully advanced their autonomy in the teaching and learning process. Most of the teachers are bounded to the curriculum achievement, for instance passing the national exam, instead of teaching based on what the actual class needed. Besides, teachers in Indonesia presume that teaching is a knowledge transfer activity, instead of allowing the students to wonder and to try to find the knowledge themselves. 
In Meisani and Rambet (2017), the teachers presume that both teachers and students have an important role in developing learner autonomy. Meanwhile, Ahsanu (2017) mentioned that teacher should also act an advisor to their students. However, the teachers' different perception on the nature of learner autonomy affects their application of learner autonomy in the classroom (Agustina, 2017). It is important to set the difference between teachers' varied understanding and their misunderstanding of learner autonomy. Another finding by Maulana, et. al. (2016) stated that teacher who develops high-quality autonomy could support the development of learner autonomy. Presumed that the pre-service teacher will become the in-service teacher soon, it is important for them to start developing their autonomy so that they could motivate their students to develop learner autonomy.

Limited research had investigated the pre-service teachers' perception of learner autonomy as a student and future teacher. Based on the aforementioned problems, the perception of the teachers and students' role in learner autonomy along with the importance of developing autonomy for the pre-service teachers play important role in learner autonomy development. This study aimed to explore the preservice teachers' perception on the role of both teachers and students in the implementation of learner autonomy also their autonomous learning activity as a student in teacher education school.

Wide-ranging explanation of learner autonomy has been the one most quoted in the research (Benson, 2007). There are four features in Holec's (1981) definition. First, autonomy is an "ability to take charge of one's own learning", which means learner autonomy is an attribute of the learner, not the process.
Second, this attribute is not innate or inborn but necessarily is acquired through a systematic and purposeful learning process. Third, it designates a potential capacity to act in a learning situation and not the actual behavior of an individual in that situation. In other words, learner autonomy cannot be identified as one single simple behavior in a particular learning situation. The fourth feature is related to learners' ability to take control of their learning by becoming responsible for the decisions made in all the aspects of the learning process. This definition highlights 'responsibility' and 'capacity' as key features of learner autonomy. From this broad definition, many definitions of learner autonomy have followed.

Little (1999) argues that since the word 'autonomy' has some popular connotations such as individual freedom and independence, 'autonomy' in the learning environment is often mistakenly understood as a type of learning without a teacher. Autonomy, according to Benson (1997), can be observed in circumstances where the students take the lead in their own learning, potentially after formal schooling has ended, and he states that the primary issue for educators is how to improve learners' abilities to take on such autonomy when the need arises.

Finally, Dickinson cited in Benson (2011) describes 'autonomy' in terms of the learner's taking full responsibility for all learning decisions in the classroom, whereas Andreu as cited in Shahsavari (2014) approaches 'autonomy' more as an attitude towards learning that rests on the recognition that the learner has responsibilities for their own learning outcomes. It can be concluded learner autonomy is considered as students' awareness of their own learning progress and the ability to manage it. 
Learner autonomy in foreign language learning depends on the ability and willingness of the learner to complete both specific and general tasks, and three areas where this autonomy is most relevant in foreign language learning is in communication, learning, and personal development (Littlewood, 1996). Similarly, Little (2004) believes that "autonomy in language learning is underpinned by three general pedagogical principles: learner involvement, learner reflection, and appropriate target language use".

There are a number of terms related to autonomy that can be distinguished from it in various ways. Most people now agree that autonomy and autonomous learning are not synonyms of, 'self-instruction', 'selfdirection', 'self-access', 'distance learning', or 'out-of-class learning'. Self-instruction refers to "learning without a teacher" (Little, 1991); or "learning without the direct control of a teacher" (Dickinson, 1987). Benson (2006) defines this term from two senses. In the narrow sense, self-instruction refers to the use of printed or broadcast self-study materials. In a broader sense, it refers to situations in which learners undertake language study largely or entirely without the aid of teachers.

Self-direction can be defined as "a particular attitude to the learning task, where the learner accepts responsibilities for all the decisions concerned with his learning but does not necessarily undertake the implementation of those decisions" (Dickinson, 1987), or "the process or the techniques used in directing one's own learning" (Holec, 1981).

Self-access refers to "learning from materials and facilities that are organized to facilitate learning; selfinstruction in using these materials" (Dickinson, 1987). The term is neutral as to how self-directed or other directed the learners are. Gardner and Miller (1999) book on self-access is the most comprehensive work in this field. Since its publication, the difficulty of making self-access centers work independently of teacher-support for autonomy has become a prominent theme in the literature. There has also been a shift of attention from the organization of selfaccess centers to the integration of selfaccess learning with coursework (Benson, 2006).

Distance learning is a way of organizing learners which usually only allows them to control over access (Lewis cited in $\mathrm{Xu}, 2006$ ). Distance learning has begun to merge with CALL through concepts such as 'online learning', 'cyber-schools', 'asynchronous learning networks' and 'telematics', in which issues of autonomy are less frequently discussed (White, 2003, cited in Benson, 2006).

The term often narrowly used to refer to the efforts of learners taking classroom-based language courses to find opportunities for language learning and use outside class (Benson, 2006). Benson also points out that recent study suggests that students tend to engage in out-of-class activities more frequently than their teachers know, often showing considerable creativity in situations where opportunities for out-of-class learning appear to be limited.

In brief, these terms basically describe various ways and degrees of learning by oneself, whereas autonomy refers to abilities and attitudes (Benson, 2005). The point is, then, that learning by oneself is not the same thing as having the capacity to learn by oneself. Also, autonomous learners may well be better than others at learning by themselves (hence the connection), but they do not necessarily have to learn by themselves. The relationship between learning 
beyond the classroom and autonomy is complex. On the one hand, all the modes of learning discussed above involve autonomous learning as Dickinson (1987) defined it. On the other, they demand a capacity for autonomy as Holec (1981) and others have defined it.

Since Little (1995) defined 'teacher autonomy' as the teachers' "capacity to engage in self-directed teaching" many scholars have tried to expand on this definition. Teacher autonomy is defined by Smith (2001) as "the ability to develop appropriate skills, knowledge, and attitudes for oneself as a teacher in cooperation with others". In addition, Smith (2001) argues that for a teacher to be autonomous he or she needs to be self-directed (and have the capacity to be self-directed) in both their action and their professional development, while also asserting their freedom in their action and professional development.

Regarding teacher roles, Yang (1998) states that teachers are taking on new roles as consultants and active participants who work alongside their students, assisting them in their own development and in acquiring techniques of learning. Demirtaş and Sert (2010) on the other hand, view the teacher as both counselor and facilitator who help students develop and utilize particular skills. Finally, Little (2004) clarifies that teacher autonomy requires the right balance between claiming responsibility for the classroom and providing students with the necessary skills and knowledge to be successful on the one hand, and knowing when to give up control and allow their students to assume more responsibility on the other.

According to Barfield et. al. as cited in Balçıkanlı (2010), students' autonomy is dependent on whether their teacher creates a classroom culture which accepts autonomy. Offering a profile of the ideal 'autonomous teacher', De Vries and Kohlberg cited in Balçıkanlı (2010) describe an autonomous teacher as the one who is grounded in her practical and theoretical convictions; who not only understands how children or students think but also knows how to promote a constructive culture in the classroom. For them, such a teacher does not blindly follow the guidelines provided by curriculum specialists and takes greater responsibility to adapt the curriculum to the needs of the students instead.

With regard to fostering teacher autonomy, Balçıkanlı (2009) claims that successful language teacher education requires the cultivation of teacher autonomy so that teachers become more aware of the underlying processes of teaching (i.e. the reasons why they pursue particular strategies) and stay abreast of new ideas in their field. As can be seen teacher autonomy is a teacher's ability to be creative and to encourage learner autonomy is dependent on 1) the teacher's relationship to his or her own teachers and partners; 2) the teacher's relationship to his or her own students; 3 ) the teacher's relationship to the institutions in which he or she is teaching, and 4) the teacher's relationship to external institutions and bureaucracies in the society.

The definitions of LA have been changing with times, among which Holec's (1981) has remained the most widely cited definition in the world. "Ability" is often replaced by "capacity", while "take charge of" is often replaced by "take responsibility for" (Benson, 2011). It pays much attention to an attribute of learners rather than learning situation. In the context of foreign language learning. Holec (1981) defines autonomy as the ability to take charge of one's own learning. An autonomous learner is, therefore, a person who is 
capable of taking charge of his or her own learning. The role of the teacher for autonomous learners is to help them to assume the responsibility for making decisions of their learning in: 1) determining the objectives; 2) defining the contents and progressions; 3) selecting methods and techniques to be used; 4) monitoring the procedure of acquisition properly speaking (rhythm, time, place, etc); 5) evaluating what has been acquired.

Furthermore, Al Asmari (2013)

believes that the teacher plays a crucial role in promoting learner autonomy by creating a learning environment that is conducive to this approach, by firstly understanding and addressing the past learning experiences of their students and then increasingly promoting independence. As to the roles of the teacher in autonomous learning, Joshi (2011) states that "a teacher in autonomous learning is a facilitator, an organizer, a resource person providing learners with feedback and encouragement, and a creator of learning atmosphere and space. In other words, a teacher works as a guide, a co-operative and an initiator rather than an authority". Additionally, according to Voller (1997), teachers in the context of autonomous learning are often characterized as 'facilitators', 'counselors', or 'resources'. At times, they are described as 'facilitators' given that they facilitate self-driven, individualized learning among the learners. Their role can also be understood as 'counselor', in that they offer guidance and suggestions for individualized learning. However, Voller (1997) asserts that the most relevant description for teachers in an autonomous learning environment is that of 'resource' for the learners. Thavenius as cited in Benson (2011) on the other hand, defines an autonomous teacher as the one who is independent in his or her own right and thus capable and adaptive enough to allow his or her learners to be independent as well.

Most teachers would agree that the goal and significance of teaching are to bring about changes in learners. And their aim is to do so effectively. However, Voller (1997) points out what those changes might be, and how they can be effectively brought about, are determined by a complex set of interrelated that depends upon what the learner and the teacher perceive their respective roles to be, and upon a set of decisions, both taken by them and imposed upon them, and experiences, both past and present, that they bring with them to any given learning situation. So complex is the relationship between these factors that one feature of many methodologies of language learning is to ignore, or at least marginalize, the teacher's role. This has been true both of language acquisition theory and of some methods associated with language learning and the learnercantered classroom. It is clear, therefore, from the above illustration that the teacher's role in fostering LA should be well considered and not be ignored.

\section{METHOD}

This study was designed in quantitative research, where the data were collected by employing a survey. Ary, Jacobs, and Sorensen (2010) explain the survey as a research method where the researcher or the investigator could analyze someone beliefs, opinion, characteristics, and behavior. It is a suitable method to pursue the objective of this study, which is to find out the preservice teacher perception and activity in learner autonomy. The survey was done by distributing a questionnaire in which used as the instrument of this study. The questionnaire, as stated by Brown 
(2001), is sets of questions or statements where respondents have to give their response as their opinion. Researcher believes that questionnaire an adequate instrument to this study's data collection.

The population of this study is the students of one private Teacher and Education Institution in Indonesia majored in English Education Programme. The sample selected form students who are still on and had finished their teaching practice, to meet the preservice teacher characteristics. In order to select the sample, the researcher did purposive sampling from the population. Purposive sampling allows the researcher to decide the sample deliberately based on the characteristic needed (Cohen, Manion, \& Morrison, 2005). Consequently, 25 pre-service teachers, where 10 pre-service teachers are on their teaching practice in 2017/2018 and 15 pre-service teachers have done their practice in 2016/2017 academic year, selected as the participant of the study.

The data were collected by adopting the instrument by Joshi (2011) framework. The questionnaire consisted of two-part where the first part related to the pre-service teachers' autonomous learning and the second part focused on their perception of learner autonomy. The first part of the questionnaire contained the participants' autonomous learning activities such as learner awareness (item 1-3), self-effort (item 48), broader autonomous activities (item 9-13), self-esteem (item 14), use of reference materials (item 15-16), motivation(item 17), and use of technology in learning (item 18). The second part of the questionnaire consists of their perception on students' role (item 19-23) and teachers' role (item 2430).

The collected data calculated first through descriptive statistics. The descriptive statistic used to summarise data tendencies (Creswell, 2012). The calculation included mean, median mode and the frequencies of the responses in percentages. The standard deviation also calculated to make sure the deviation of the score to the whole population. After that, the calculation result presented based on the category from Joshi (2011) framework, which is the autonomous learning activity and the perception on teachers and students' role in learner autonomy.

\section{RESULTS AND DISCUSSION}

The first research question answered by the data collected from the first part of the questionnaire. The data were classified into seven subheadings: learner awareness, self-effort, broader autonomous activities, self-esteem, use of reference materials, motivation, and use of technology in learning.

\section{Learner Awareness}

Around $68 \%$ of respondents thought that they were a good English language learner. The rest were not sure about their English learning ability (28\% sometimes, $4 \%$ never). Regarding item number 2, the majority of the respondents made their goals in learning frequently (48\% always, $28 \%$ often). The last item on the learner awareness was the optimization of their free time to learn English, only $28 \%$ answered often and $8 \%$ always. It can be said that the majority of the respondents were aware of their learning progress, yet only a few of them use their free time to improve their English proficiency. These activities are in line with what Holec (1981) and Dickinson (1987) have in mind. The learners are intended to be responsible to carry out the learning activity by themselves without teachers command. Although the finding indicates that only a few who did make a 
learning goal or learn in their free time, these findings still indicate that there is autonomous learning activity that is going on.

\section{Self-Effort}

In making effort to check their note of the previous lesson before the next lesson, about 52\% responded they did it sometimes and $20 \%$ rarely did it. The majority of the respondents tried to take every opportunity they see in the class to participate and communicate in English (52\% often \& $8 \%$ always). In term of confidence, $40 \%$ agreed that they were often confident to speak in English in front of others; meanwhile, $20 \%$ of the respondents were rarely confident. In order to support their learning outside the class, $44 \%$ of respondents stated that they took a note of the lesson ( $24 \%$ often $\& 20 \%$ always). However, the same number of percentages stated that they only took note occasionally. Another item of the self-effort is their effort to communicate with their teachers and friends in English outside of the class, $84 \%$ responded to sometimes. The data indicate that the respondents made the various effort to their learning process such as taking a note and participating in the class action. Although the respondents argued that they were confident, only small proportion took the chance to speak in English outside of class. These findings supported by Holec (1981) who believes the technique that they use are meant to develop their autonomous learning activity. The researcher found that the percentage of 'sometimes' choice is higher than their choices, it does not mean that their actions were not categorized as autonomous learning. As what Dickinson (1987) said, the learners have to be responsible in deciding how to achieve the learning, although their decision does not necessarily undertake the implementation. It means that the learner decides the learning process by themselves base on what they think suite them, even though they might not carry the activity fully.

\section{Broader Autonomous Activities}

Not only in the class, $44 \%$ of respondents claimed that they also practice outside class (36\% often \& 8\% always). In contrast to the statement of item $9,40 \%$ ( $24 \%$ never \& $16 \%$ rarely) stated that they did not rely on the library to improve their English. The largest proportion of the broader autonomous activity went to the usage of audio-visual material $(28 \%$ sometimes, $36 \%$ often, and $28 \%$ always). In addition to that, $40 \%$ of respondents attended seminar, courses or conference to improve their English, yet $16 \%$ had never been to any. Over half of the population claimed that they took a risk in learning English (32\% often \& 28\% always). It can be concluded that most of the respondents prefer audio-visual material on their own rather than staying and using materials which available in their library. These findings supported by Dickinson (1987) and Gardner \& Miller (1999), they explain that teacher, as the only source is not enough, therefore learners have to find other source material that usually found in self-access center or in a library. Even though the number participant who visited the library is relatively small, this condition covered by other self-accessed sources, such as seminars, courses, vlog and many more.

\section{Self-Esteem}

This trait was collected through question item number 14 . The data found that $48 \%$ sometimes evaluate their progress in learning, followed by $28 \%$ often and $12 \%$ always. This finding indicates that the respondents were aware of their own progress and tried to 
evaluate it. As explained in the "nature of learner autonomy', learner autonomy refers to not only the learning alone but also the evaluation as part of the learning process. It is necessary for the learner to evaluate their learning. This process allows them to be more independent in their learning.

\section{Use of Reference Materials}

About $20 \%$ of the respondents claimed that they always revise their lesson and sought another source of material to support it, followed by $16 \%$ often and $48 \%$ sometimes. However, only $20 \%$ ( $16 \%$ often \& $4 \%$ always) of the respondents who read extra material they found besides the one prescribed to them. Even though some of the respondents expand their learning by looking for other sources, only a few of them actually did it in advance. Similar to the previous activity, Dickinson (1987) explains the importance of decision making in learner autonomy does not only focuses on the method used in learning but also the material used. The majority of the respondents rely on the material prescribe by the teacher and only a few south for extra material. Researchers believe that this side of learner autonomy activities is not well developed.

\section{Motivation}

About 52\% disagree on rewarding themselves over their achievement (28\% never \& $24 \%$ rarely). Only $24 \%$ rewarding themselves by buying stuff, celebrating parties, etc. It indicates the low level of selfappreciation in their learning progress. Not only deciding and evaluating, but motivation also plays important role in the autonomous learning activity. Students who satisfied with their own progress will treat themselves to motivate them in learning again, and vice versa.

\section{Use of Technology in Learning}

As large as $68 \%$ proportion answered that they always use technology to support their learning. This finding showed their awareness of technology as one of learning source. The use of technology in the $21^{\text {st }}$ century cannot be denied, this technology also found to be useful in learner autonomy. White (cited in Benson, 2006) the development of technology allows the students to have out-of-class learning in which is believed that it could help the students in developing their learner autonomy. The second part of the questionnaire collected the data that needed to answer the second research question on the pre-service teachers' perception on the role of the teachers and students in learner autonomy activity.

\section{Students' Role}

The majority agreed and strongly agreed $(48 \%$ and $32 \%$ respectively) that the students have to be responsible to find a way to their own practice. Similar to that, $64 \%$ agree and $24 \%$ strongly agreed that students have to use the much self-studying material. In addition to that students have to be able to evaluate their own learning (52\% agree \& $40 \%$ strongly agree). In contrast to the first three statements, in the total of 56\% agreed and strongly agreed that students should only learn from topic mentioned by the teacher in order to pass the exam. It is believed that the view of the pre-service teachers on the goal of a lesson was to pass an exam. Not only to that, but $52 \%$ also agreed that students have to make sets of plans and aim in their learning progress so that they can have a clear vision of it. Holec (1981) and Dickinson (1987) stated that students have to be responsible for their 
learning which includes the decision making on 'how to learn' and 'what to learn'. Although the respondents agreed on what Holec and Dickinson stated, their view on learning still oriented on examination. Their view is the opposite of 'what to learn' decision-making, learner should decide the learning because they think they need to know the answer not because they need to pass school examination This view is also contradicted to what Benson's (2008, 2011) idea where learner autonomy able to let the students be successful beyond school.

\section{Teachers' Role}

The perception of teachers' existence is not necessary for the autonomous learning were varied as $16 \%$ strongly disagreed and $28 \%$ disagreed, meanwhile $32 \%$ agreed and $12 \%$ strongly agreed. In contrast to the teacher's existence, teachers were the one who has to be responsible for the success of the students' learning achievement (40\% agree \& $48 \%$ strongly agree). In addition to that, $44 \%$ agreed and $28 \%$ strongly agreed that teacher should point out the student's error. The respondents strongly agreed $(76 \%)$ that teaching is not to teach 'what' but 'how'. Supporting the previous statement of item 22, $80 \%$ respondents agreed and strongly agreed that teacher should provide notes related to exam topic. Meanwhile, the failures faced by the students were due to teachers wrong teaching method implementation (36\% agree \& $12 \%$ strongly agree). The last item is how teachers should use their authority in the learning activity, 68\% agreed with this statement. It can be pointed out that the perception of teachers' role was mostly teacher cantered rather than students centered. The respondents view on the teacher, mainly, like the one that is responsible to the learner achievement, instead of as the facilitator, and source of learning. These findings are contradicted to the nature of learner autonomy, where the learner is the one that has to be responsible for the 'achievement'.

\section{CONCLUSION}

It can be concluded that the majority of the pre-service teacher aware of the progress they made. To support the progress, some respondents stated that they took note during the lesson and read it again after the class as a reference. In term of speaking even though majority claimed have used all the chance they have to speak, however only partial who was confident enough to speak outside of the class. Other activities done by the respondents include attending a seminar, conference and courses to improve their English. The respondents' self-esteem indicates that they were capable of evaluating themselves although they did it sometimes only. Not only to the source given by their teacher, respondents stated that they also look for another source for their learning, however only a few of them actually read it in advance. Then, the motivation, half of the participants did not consider it was necessary to reward themselves. The last is technology usage, almost all respondents agreed to it as the source of learning. Regardless their awareness to their learning progress, only a few of it that actually did learn autonomously. It is perhaps due to their lack of understanding on the natural science of the learner autonomy itself.

In addition to that, the preservice teachers thought teachers' role was still the dominant part of learner autonomy. The respondents also mentioned it important to learn only from what had prescribed on the course to pass the exam. Moreover, if a failure occurred in students learning 
achievement, it was teachers' fault at implementing teaching method. It means that their view of learner autonomy still lingered on teacher-centered method. It is contradicted to what learner autonomy aimed for, where the students were in charge of their decision to what they want to learn and how to achieve it.

Overall, it can be concluded that the pre-service teachers' lack of understanding of learner autonomy resulted in their low level of autonomous learning. This result was the opposite of the original by Joshi (2011) such as the use of technology were used less rather than other self-effort activity. However, the perception of the teachers' role was almost identical; the learning process might be done without teachers, yet the teachers' role still an important component of the learning.

\section{REFERENCES}

Agustina, D. (2017). Teachers' understanding of learner autonomy in indonesian contexts: findings from high schools and their implications. Language and Language Teaching Journal, 20(2), 127-132.

Ahsanu, M. (2017). Fostering EFL learner autonomy in Indonesian context. Issues in Applied Linguistics and Language Teaching, 1(1), 12-19.

Al Asmari, A. (2013). Practices and prospects of learner autonomy: teachers' perceptions. English Language Teaching, 6(3), 1-10.

Ary, D., Jacobs, L. C., \& Sorensen, C. (2010). Introduction to Research in Education (Vol. VIII). Canada: Wadsworth, Cengage Learning.

Balçıkanlı, C. (2009). Teacher autonomy: a qualitative research study with student teachers. IATEFL Learner Autonomy Special Interest Group, 46, 8-13.
Balçıkanlı, C. (2010). Learner autonomy in language learning: student teachers' beliefs. Australian Journal of Teacher Education, 35(1), 90-103.

Benson, P. (1997). The philosophy and politics of learner autonomy. In P. Benson \& P. Voller (eds), Autonomy and independence in language learning, (pp. 18-34). London: Longman.

Benson, P. (2005). Teaching and Researching Autonomy in Language Learning. Beijing: Foreign Language Teaching and Research Press.

Benson, P. (2006). Autonomy in language teaching and learning. Language Teaching, 40, 21-40.

http://dx.doi.org/10.1017/S0261444806 003958

Benson, P. (2007). Autonomy in language teaching and learning. Language Teaching, 40(01), 21 40. doi: $10.1017 / \mathrm{S} 0261444806003958$

Benson, P. (2008). Teachers' and Learners' Perspectives on Autonomy. In T. Lamb, \& $\mathrm{H}$. Reinders, Learner and Teacher Autonomy: Concepts, Realities, and Responses (pp. 15-31). Philadelphia: John Benjamins.

Benson, P. (2011). Teaching and Researching Autonomy (2nd ed.). London, England: Pearson.

Brown, J. D. (2001). Designing Surveys for Language Programs. Cambridge: Cambridge University Press.

Camilleri, A. (1999). Introducing Learner Autonomy in Teacher Education. Council of Europe.

Cohen, L., Manion, L., \& Morrison, K. (2005). Research Method in Education (Fifth Edition). New York: Taylor \& Francis e-Library. 
Creswell, J. W. (2012). Educational Research: Planning, Conducting, and Evaluating Quantitative and Qualitative Research (Fourth Edition). Boston: Pearson Education Inc.

Demirtaş, İ., \& Sert, N. (2010). English education at university level: who is at the Centre of the learning process? Novitas Royal (Research on youth and language), 4(2), 159172.

Dickinson, L. (1987). Self-Instruction in Language Learning. Cambridge: Cambridge University Press.

Esch, E. (1996). Self-Access and the Adult Language Learner. London: Centre for Information on Language Teaching and Research.

Gardner, D., \& Miller, L. (1999). Establishing Self-Access: From Theory to Practice. Cambridge University Press.

Harmer, J. (2007). The Practice of English Language Teaching (4th ed.). London: Pearson Longman ELT.

Holec, H. (1981). Autonomy and Foreign Language Learning. Oxford: Council of Europe.

Agustina, D. (2017). Teachers' understanding of learner autonomy in indonesian contexts: findings from high schools and their implications. Language and Language Teaching Journal, 20(2), 127-132.

Ahsanu, M. (2017). Fostering EFL learner autonomy in Indonesian context. Issues in Applied Linguistics and Language Teaching, 1(1), 12-19.

Al Asmari, A. (2013). Practices and prospects of learner autonomy: teachers' perceptions. English Language Teaching, 6(3), 1-10.

Ary, D., Jacobs, L. C., \& Sorensen, C. (2010). Introduction to Research in Education (Vol. VIII). Canada: Wadsworth, Cengage Learning.

Joshi, K. R. (2011). Learner perceptions and teacher beliefs about learner autonomy in language learning. Nepal English Language Teachers' Association, 16(1-2), 13-29.

Little, D. (1991). Learner Autonomy. Dublin: Authentik.

Little, D. (1995). Learning as dialogue: the dependence of learner autonomy on teacher autonomy. System, 23(2), 175-181.

Little, D. (1999). Developing learner autonomy in the foreign language classroom: A social-interactive view of learning and three fundamental pedagogical principles. Revista Canaria de Estudios Ingleses, (38), 77-88.

Little, D. (2004). Democracy, discourse and learner autonomy in the foreign language classroom. Utbildning \& Demokrati, 13(3), 105-126.

Littlewood, W. T. (1996). Autonomy: an anatomy and a framework. Pergamon, 24(4), 427-435.

Maulana, R., et. al. (2016). Autonomous motivation in the Indonesian classroom: relationship with teacher support through the lens of self-determination theory. AsiaPacific Education Researcher, 25(3), 441-451.

Meisani, D. R., \& Rambet, R. D. (2017). Teachers' beliefs regarding language learner autonomy and practices of project-based education: a case study of an Indonesian EFL teacher. Nobel: Journal of Literature and Language Teaching, 8(2), 67-75.

Shahsavari, S. (2014). Efficiency, feasibility and desirability of learner autonomy based on teachers' and learners 'point of 
views. Theory and Practice in Language Studies, 4(2), 271-280.

Smith, R. C. (2001). Teacher education for teacher-learner autonomy. Language in Language Teacher Education, a lecturer in the Centre for English Language Teacher Education (CELTE). University of Warwick.2001-homepages. Warwick.au.uk.

Smith, R. C. (2003). Teacher education for teacher-learner autonomy. Centre for English Language Teacher Education (CELTE), 1-9. Retrieved from http://www. warwick. ac. uk/ elsdr/Teacher
Voller, P. (1997). Does the teacher have a role in autonomous language learning? In P. Benson and P. Voller (eds), Autonomy and independence in language learning, (pp. 98-113). London: Longman.

$\mathrm{Xu}, \mathrm{J} . \mathrm{F}$. (2006). The theory and practice of university foreign language autonomous learning. Beijing: China Social Sciences Publishing House.

Yang, N. D. (1998). Exploring a new role for teachers: promoting learner autonomy. System, 26(1), 127-135. 